\title{
Length-Weight and Length-Length Relationships of the Levantine Barbel Luciobarbus pectoralis (Heckel, 1843) in Asi River, Turkey
}

\author{
Sibel ALAGÖZ ERGÜDEN \\ Çukurova University, Vocational School of Imamoglu, Depertmant of Fisheries 01700, Imamoglu, Adana, Turkey
}

How to cite: Alagöz Ergüden, S. (2020). Length-Weight and Length-Length Relationships of the Levantine Barbel Luciobarbus pectoralis (Heckel, 1843) in Asi River, Turkey. J. Anatolian Env. and Anim. Sciences, 5(4), 454-459.

Atıf yapmak için: Alagöz Ergüden, S. (2020). Asi Nehri (Türkiye)'nde Bulunan Bıyıklı Balık Luciobarbus pectoralis'in (Heckel, 1843) Boy-Ağırlık ve BoyBoy İlişkileri. Anadolu Çev. ve Hay. Dergisi, 5(4), 454-459.

https://orcid.org/0000-0002-9061-9581

*Corresponding author's: Sibel ALAGÖZ ERGÜDEN Çukurova University, Vocational School of Imamoglu, Depertmant of Fisheries, 01700 Imamoglu, Adana, Turkey

\: alagozs@cu.edu.tr

Mobile telephone : $+90(538) 3281757$

Telephone : $+90(322) 8912520$

Fax : +90(322) 8912521

\begin{abstract}
Length-weight and length-length relationships are significant in fish biology. These parameters can provide information on the stock condition and growth studies. In this study, we report the length-weight and length-length relationships for Luciobarbus pectoralis in the Southeastern Anatolia (Hatay, Turkey). A total of 125 (65 female and 60 male) specimens were captured from Asi River (Orontes River) basin using gill nets in September 2015 and March 2016. The total length and weight of both sexes varied from $15.5-38.0 \mathrm{~cm}$ and $35.0-855.0 \mathrm{~g}$. The values of the exponent $b$ of the length-weight relationships were 3.441 for females and 3.443 for males. The length-length relationship between total, fork and standart (TL, Total Length-FL, Fork Length, SL, Standart Length) length measurements were found high correlated $\left(R^{2}>0.99\right.$, $\mathrm{P}<0.001)$. This study provides the first comprehensive description of LWRs and LLRs of $L$. pectoralis from the Asi River (Hatay, Turkey) according to their sexes. Besides, new maximum length and weight values are reported for $L$. pectoralis.
\end{abstract}

Keywords: Cyprinidae, Hatay province, length, Orontes river basin, regression parameters, weight.

\section{Asi Nehri (Türkiye)'nde Bulunan Bıyıkı Balık Luciobarbus pectoralis'in (Heckel, 1843) Boy-Ăğırık ve Boy-Boy İlişkileri}

*Sorumlu yazar:

Sibel ALAGÖZ ERGÜDEN

Çukurova Üniversitesi, İmamoğlu Meslek

Yüksekokulu, Su Ürünleri Bölümü, 01700, İmamoğlu, Adana, Türkiye.

凶: alagozs@cu.edu.tr

Mobile telephone : $+90(538) 3281757$

Telephone : $+90(322) 8912520$

Fax $\quad:+90(322) 8912521$
Öz: Balık biyolojisinde boy-ağırlık ve boy-boy ilişkileri oldukça önemlidir. Bu parametreler, stok durumu ve büyüme çalıșmaları hakkında bilgi sağlamak içindir. Bu çalışmada, Güneydoğu Anadolu'da (Hatay, Türkiye) bulunan Luciobarbus pectoralis'in uzunluk-ağırlık ve uzunlukuzunluk ilișkileri tespit edilmiștir. Eylül 2015 ve Mart 2016 tarihlerinde Asi Nehri (Orontes Nehri)'nden solungaç ağları iletoplam 125 (65 dişi ve 60 erkek) örnek yakalanmıştır. Tüm bireyler için örneklerin total boyu ve ağırlığı 15.5-38.0 cm ve 35.0-855 g arasında değișim gösterdi. Boyağırlık ilişkilerinin b üssi katsayısı, dişiler için 3.441 ve erkekler için 3.443 hesaplandı. Toplam, çatal ve standart boy ölçümleri (TL, Toplam Boy-FL, Çatal Boy, SL, Standart Boy) ve boy-boy ilişkisi arasında yüksek derecede korelasyon bulundu $\left(\mathrm{R}^{2}>0.99, \mathrm{P}<0.001\right)$. Bu çalışmada Asi Nehri'ndeki (Hatay, Türkiye) L. pectoralis' in boy-ağırlık ve boy-boy ilişkilerinin cinsiyetlerine göre ilk kapsamlı tanımlaması yapılmaktadır. Ayrıca bu çalışmada $L$. pectoralis için yeni bir maksimum uzunluk ve ağırlık bildirilmiştir.

Anahtar kelimeler: Ağırlı, Asi nehir havzası, boy, cyprinidae, Hatay ili, regresyon parametreleri. 


\section{INTRODUCTION}

Luciobarbus pectoralis (Heckel, 1843) is a Levantine barbel species found in the south-east Mediterranean region (Fricke et al., 2007). It is widespread in the lower Göksu, Seyhan and Ceyhan drainages (Erguden, 2016) and all over Asi drainage in Turkey (Kottelat \& Freyhof, 2007; Ozcan, 2013) and Syria (Freyhof, 2014; Froese \& Pauly, 2020).

L. pectoralis has been considered as a valid species by most authors (Karaman 1971; Geldiay \& Balık, 1999; Kuru, 2004; Turan et al., 2008) and this species commonly occur from the Orontes basin (Almaça, 1986; Kottelat \& Freyhof, 2007). L. pectoralis is very similar to $L$. capito. $L$. pectoralis is distinguished from the other conspecific, $L$. capito by having total lateral line scale counts (50-55 vs. in L. pectoralis; 52-72, usually 60-66 in L. capito), and gill raker counts (17-19 gill rakers on the first gill arch vs. 17-18 in L. pectoralis; 12-18 in L. capito), (Turan et al., 2008).

The knowledge on length-weight (LWRs) and length-length relationships (LLRs) of fish is helpful in fisheries science. Length and weight relationships are used widely in fisheries exploitation and management. LWRs are essential to recognize the ecology and life cycle of fish species and also very useful to predict weights from more effortless measures of lengths (Froese, 2006; Santos et al., 2002). Besides, LLRs are also great importance for comparative growth studies (Moutopoulos \& Stergiou, 2002). These relationships are commonly used in fisheries biology and population dynamics to determine the population structure and stock status of a fish species (Bagenal \& Tesch, 1978)

To date, there is no information on LWRs and LLRs for $L$. pectoral is according to their sexes from Southeastern Anatolia, Turkey (Asi River, Hatay). Besides, no info regarding this fish species for Asi River Basin is available in Fishbase (Froese \& Pauly, 2020). This study provides the first information on LWRs and LLRs relationships of Levantine barbel collected in Asi River, Turkey (Southeastern Anatolia, Hatay, Turkey).

\section{MATERIAL AND METHOD}

Fish samples were collected from two localities in the Asi (Orontes) River drainage (south-eastern Anatolia, Turkey) between September 2015 and March 2016 using gill nets (40 and $44 \mathrm{~mm}$ mesh sizes) set at 0-2 $\mathrm{m}$ depths (Coordinates: 36 30' N,36 24' E - 36 25' N, 36 33' E) (Figure 1). Specimens were transported on ice in a cooler box to the laboratory at Cukurova University. Total length (TL), Standard length (SL), and Fork length (FL) were measured to the nearest millimeter (mm) and total weight (TW) nearest 0.01 gram (g), respectively. Sexes were identified by macroscopic and microscopic examination of the gonads.
Mean length and mean weight for males and females were compared using Student's t test. Statistical differences in thesex ratio were determined using the Chi-square $\left(\chi^{2}\right)$ test.

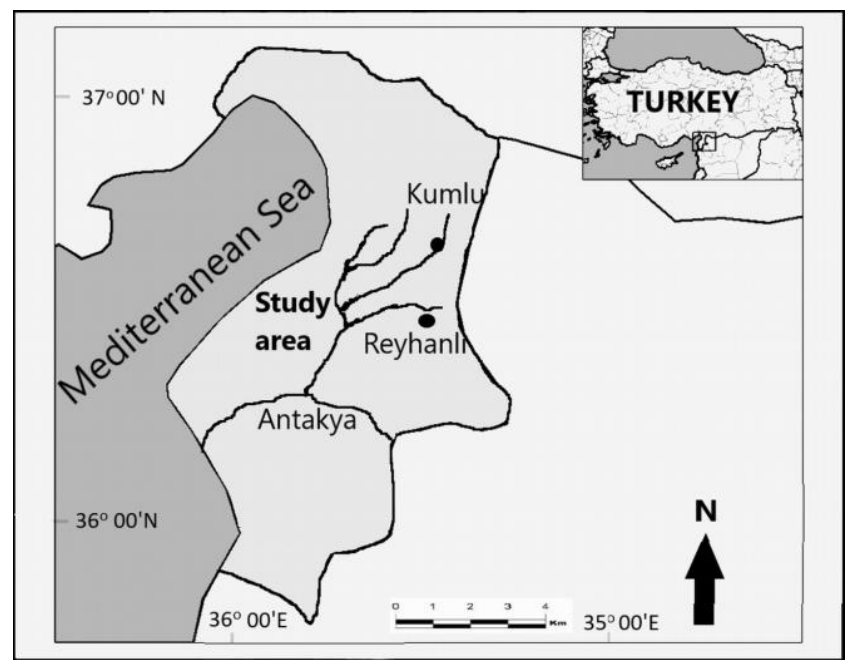

Figure 1. Sampling locations $(\bullet)$ in the Asi River Basin.

The LWRs was $\mathrm{W}=\mathrm{TL}^{\mathrm{b}}$ (Ricker, 1975), the statistical significance level of $\mathrm{R}^{2}$ was estimated, and the parameters $\mathrm{a}$ and $\mathrm{b}$ calculated by linear regression equation of $\log \mathrm{TW}=\log a+b \log \mathrm{TL}$, where, $\mathrm{W}$ is the weight of the fish in grams; TL is the total length in $\mathrm{cm}$ and, $\mathrm{a}$ and $\mathrm{b}$ are the intercept and the slope of the regression line, respectively. The significance of theregression was assessed by ANOVA, and the "b" value was tested by student's t-test to verify if it was significantly different from isometric growth (Ricker, 1975; Pauly, 1984). LLRs were established using linear regression analysis: TL-SL, SL-FL and FL-TL. The analyzes were evaluated statistically using SPSS computer package program.

\section{RESULTS}

Of the 125 specimens, ranging from 15.5 to $38.0 \mathrm{~cm}$ TL, 65 were females $(52.0 \%)$ and 60 were males $(48.0 \%)$. The total sex ratio for female and male individuals (M:F) was 0.92:1.00. The difference between the sex ratio was not found to be statistically significant $\left(\chi^{2}=0.626, \mathrm{P}>0.05\right)$. The average total length values of the examined samples were foundto be $24.07 \mathrm{~cm} \pm 0.82$ (15.5-38.0) for females and $24.23 \mathrm{~cm} \pm 0.66(16.0-35.5)$ for males. There was a significant difference between both sexes in the overall total length $(\mathrm{t}=0.156, \mathrm{P}<0.05)$. The average total weight values were calculatedas $229.46 \mathrm{~g} \pm 24.44$ (35.0-850.0) for females and $180.28 \mathrm{~g} \pm 17.40$ (37.0-586.0) for males. The t test showed a significant difference between both sexes in overall weight $(\mathrm{t}=1.477, \mathrm{P}<0.05)$. The sample size, mean TL, standard error (SE) of TL, size range (cm, TL), mean W, SE of TW and total weight range $(\mathrm{g}, \mathrm{W})$ are given in Table 1 
Table 1. Total length (TL) and weight (W) of L. pectoralis in Asi River.

\begin{tabular}{llllllllll}
\hline & \multicolumn{3}{c}{ Length characteristics } & \multicolumn{3}{c}{ Weight } \\
\hline Sex & $\mathbf{n}$ & Mean & S.E. & Min & Max & Mean & S.E. & Min & Max \\
\hline Both & 125 & 24.15 & 0.53 & 15.5 & 38.0 & 206.65 & 16.69 & 35.0 & 850.0 \\
Females & 65 & 24.07 & 0.82 & 15.5 & 38.0 & 229.46 & 24.44 & 35.0 & 850.0 \\
Males & 60 & 24.23 & 0.66 & 16.0 & 35.5 & 180.28 & 17.40 & 37.0 & 586.0 \\
\hline
\end{tabular}

n: sample size; S.E: Standart Error, Min: Minimum; Max. Maximum.

The calculated allometric coefficient $b$ ranged from a minimum of 3.441 for females to a maximum of 3.438 for both sexes. The LWRs indicated a positive allometric growth for L. pectoralis (Table 2). The LWRs of L. pectoralis was calculated as $\mathrm{W}=0.0030 \mathrm{TL}^{3.441}\left(\mathrm{R}^{2}=0.974\right)$ for females, $\mathrm{W}=0.0026 \mathrm{TL}^{3.442} \quad\left(\mathrm{R}^{2}=0.983\right)$ for males, and $\mathrm{W}=0.0028 \mathrm{TL}^{3.438}\left(\mathrm{R}^{2}=0.970\right)$ for both sexes. Estimation of length-weight relationship for females, males and both sexes are shown in Figure 2 and the estimated parameters of the LWR ( $a$ and b), SE of b, confidence limit (95\%) of a and $\mathrm{b}$, and the determination coefficients $\left(\mathrm{r}^{2}\right)$ are given in Table 2 .

Linear regression was highly significant $(\mathrm{P}<0.001)$ for all species. LLRs presented in Table 3 were highly significant $(\mathrm{P}<0.001)$, with all the coefficient of determination values $\left(\mathrm{r}^{2}\right)>0.990$

\section{DISCUSSION}

In the present paper, the relations between total length (TL), fork length (FL) and standard length (SL), and between total length and weight relationships were investigated for L. pectoralis from two localities (Asi River, Turkey). The length and weight data collected throughout the sampling period are not representative for all months within a year.

The total length and total weight of both sexes

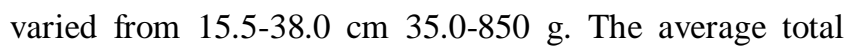
length of the examined for both sexes was found $24.15 \mathrm{~cm} \pm$ 0.53 , and the average total weight was $206.65 \mathrm{~g} \pm 16.69$. Ozcan and Ispir (2019) reported total length as $16.5-21.0 \mathrm{~cm}$ and total weight as 23.87-75.65 $\mathrm{g}$ for L. pectoralis from Menzelet Dam Lake (Kahramanmaraş, Turkey). Erguden (2016) stated that the minimum and maximum values of total lengths and weights of the samples collected from Seyhan Reservoir (Adana, Turkey) ranged between 15.5-33.5 cm and 37.0-412.7 g. Basiaciket al., (2012) declared total length as $13.2-32.3 \mathrm{~cm}$ and total weight as $40.0-572.70 \mathrm{~g}$ for $L$. kottelati collected from Adıüzel Dam Lake (Denizli, Turkey). These size and weight differences are related to sex, sampling gear, season, habitat and also considerably affected by such factors as fishing pressure, stress, reproductive activity, nutrition and environment (Le Cren, 1951; Froese, 2006). Besides, the size of fishes may fluctuate depending on sex, feeding, gonadal development, water flow, and their behavior (Tarkan et al., 2006).
Positive allometric growth values were observed for the L. pectoralis of $\mathrm{b}$ for both sexes, females, and males (Table 2, Figure 2). The values of the parameter $b$ vary between 2.5 and 3.5 (Froese, 2006). In the present study, all $b$ values fell within this expected range. The value of $b$ is different than 3 for the both sexes $(b=3.438)$, female $(b=$ 3.441) and male $(\mathrm{b}=3.443)(b>3, \mathrm{p}<0.05)$ (Table 2$)$.

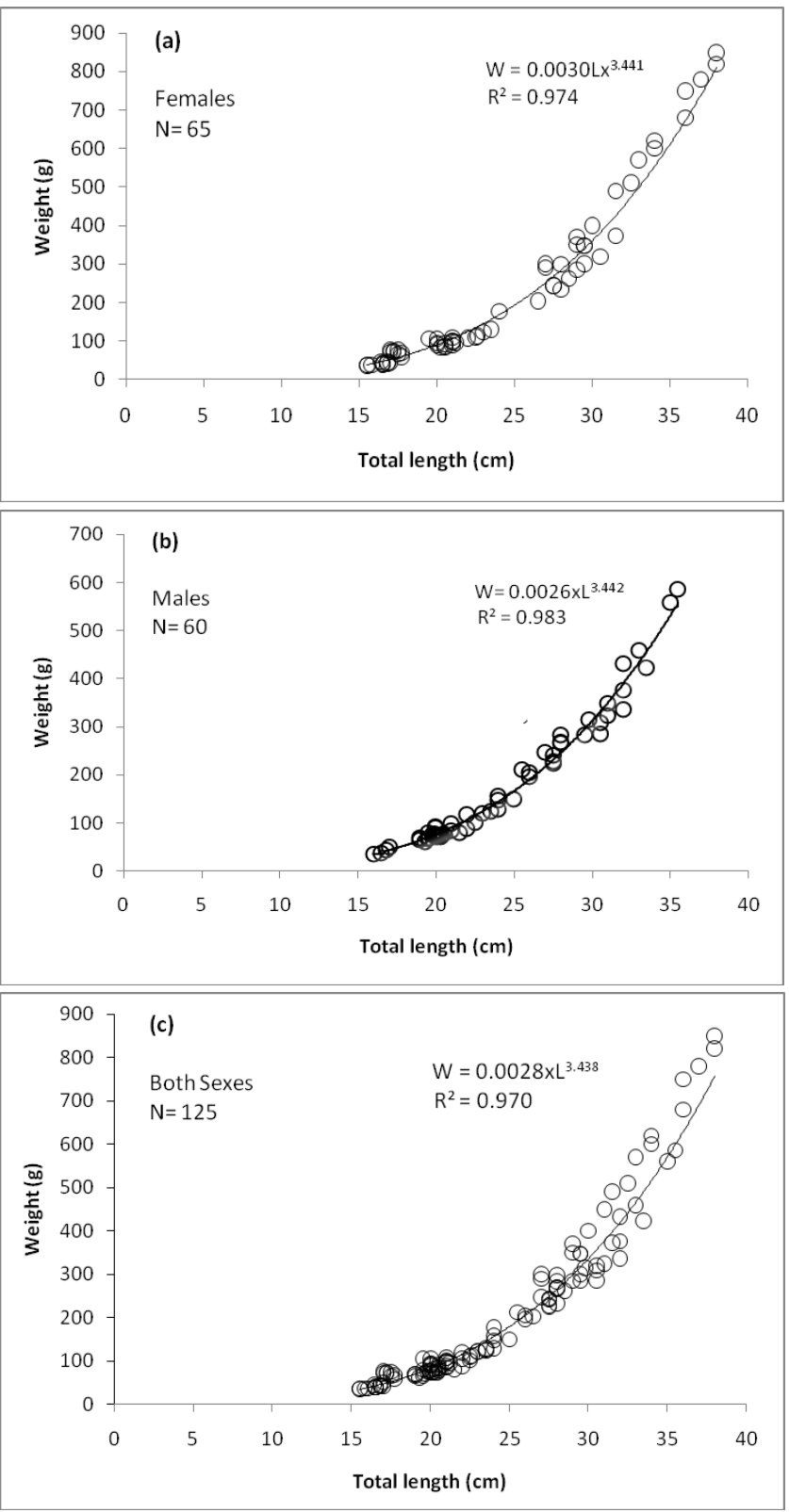

Figure 2. Length-weight relationship of females (a), males (b) and both sexes (c) for L. pectoralis in Asi River. 
Table 2. Length-weight relationships for L. pectoralis in Asi River

\begin{tabular}{lccccccccc}
\hline Sex & $\mathbf{n}$ & $\mathbf{a}$ & $\mathbf{b}$ & $\mathbf{S E}(\mathbf{b})$ & $\mathbf{9 5 \%}$ CI of a & $\mathbf{9 5 \%}$ CI of b & r2 & GrowthType & P \\
\hline Both & 125 & 0.0028 & 3.438 & 0.055 & $0.0020-0.0039$ & $3.330-3.546$ & 0.970 & A $(+)$ & P $<0.05$ \\
Females & 65 & 0.0030 & 3.441 & 0.071 & $0.0017-0.0037$ & $3.300-3.582$ & 0.974 & A $(+)$ & < $<0.05$ \\
Males & 60 & 0.0026 & 3.443 & 0.059 & $0.0019-0.0040$ & $3.325-3.561$ & 0.983 & A $(+)$ & P $<0.05$ \\
\hline \multicolumn{7}{l}{ n: Sample size, a: intercept of therelationship; b: slope of therelationship; SE (b): Standart Error of b; CI: Confidenceinte rvals of b and a; r2: Coefficient of determination. }
\end{tabular}

n: Sample size, a: intercept of therelationship; b: slope of therelationship; SE (b): Standart Error of b; CI: Confidenceinte rvals of b and a; r2: Coefficient of determination.

Table 3. Morphometric relationships between total length (TL), fork length (FL) and standart length (SL) for L. Pectoralis in Asi River.

\begin{tabular}{lllllll}
\hline Sex & $\mathbf{n}$ & Equation & $\mathbf{a}$ & $\mathbf{b}$ & SE $(\mathbf{b})$ & r2 \\
\hline BothSexes & 125 & $\mathrm{TL}=\mathrm{a}+\mathrm{bSL}$ & -0.028 & 0.967 & 0.008 & 0.995 \\
& & $\mathrm{SL}=\mathrm{a}+\mathrm{bFL}$ & 0.095 & 0.990 & 0.006 & 0.997 \\
Female & & $\mathrm{FL}=\mathrm{a}+\mathrm{bTL}$ & -0.016 & 1.026 & 0.006 & 0.998 \\
& \multirow{2}{*}{65} & $\mathrm{TL}=\mathrm{a}+\mathrm{bSL}$ & -0.120 & 0.998 & 0.009 & 0.997 \\
Male & & $\mathrm{SL}=\mathrm{a}+\mathrm{bFL}$ & 0.117 & 0.981 & 0.006 & 0.999 \\
& & $\mathrm{FL}=\mathrm{a}+\mathrm{bTL}$ & 0.015 & 1.016 & 0.006 & 0.999 \\
& \multirow{2}{*}{60} & $\mathrm{TL}=\mathrm{a}+\mathrm{bSL}$ & 0.024 & 0.950 & 0.014 & 0.994 \\
& & $\mathrm{SL}=\mathrm{a}+\mathrm{bFL}$ & 0.099 & 0.989 & 0.012 & 0.996 \\
\hline
\end{tabular}

n: Sample size, a: intercept of therelationship; b: slope of therelationship; SE (b): Standart Error of b; $\mathrm{r}^{2}$ : Coefficient of determination

There is a little study (Erguden, 2016; Ozcan \& Ispir, 2019) for this species in the inland water of Turkey. Thus, the belonging to same genus different Luciobarbus species was used compare, due to very close biological characteristics in this study. LWRs of Luciobarbus species have been reported for different regions in Table 4 . Similarly, Erguden (2016) has reported the b value as 3.225 for L. pectoralis from Seyhan Reservoir. Basiacik et al., (2012) have given b value as 3.138 from Adıgüzel Dam for L. kottelati. Tarkan et al., (2006) stated the mean value of b as 3.074 as the result of a study on the L. escherichii species collected from Omerli Dam Lake (Turkey). On the contrary, the previous report of negative allometric growthof $L$. pectoralis has also been reported by Ozcan and Ispir (2019). In their study, b value was calculated as for both sexes $b=1.778$, for the female $b=1.228$ and for the males $\mathrm{b}=2.478$, in Menzelet Reservoir (Ozcan \& Ispir, 2019). These differences of $b$ value may depend on the ontogenetic development, seasonal variation, and ecological factors (Alp et al., 2005; Wootton, 1998).

Table 4. Geographic comparison of LWRs parameters for Luciobarbus species from different areas.

\begin{tabular}{|c|c|c|c|c|c|c|c|c|c|}
\hline Species & Locality & Sex & $\mathbf{n}$ & Lengthtype & Length $(\mathbf{c m})$ & a & b & $\mathbf{r} 2$ & Author(s) \\
\hline Luciobarbus kottelati & Adıgüzel Dam, Turkey & Mixed & 144 & FL & - & 0.0009 & 3.138 & 0.975 & Basiacik et al. (2012) \\
\hline Luciobarbus escherichii & Omerli Dam, Turkey & Mixed & 12 & $\mathrm{TL}$ & $4.9-22.6$ & 0.0096 & 3.050 & 0.989 & Tarkan et al. (2006) \\
\hline Luciobarbus esocinus & Keban Reservoir, Turkey & Male & 85 & $\mathrm{TL}$ & $34.8-112.4$ & 0.0079 & 3.098 & 0.970 & Çoban et al. (2012) \\
\hline Luciobarbus esocinus & Keban Dam Lake,Turkey & Mixed & 22 & $\mathrm{TL}$ & $37.4-49.7$ & 0.0101 & 2.915 & 0.965 & Dartay \& Gül (2013) \\
\hline Luciobarbus esocinus & Gamasiab Reservoir, Iran & Mixed & 170 & $\mathrm{TL}$ & $19.4-42.2$ & 0.0060 & 2.871 & 0.970 & Hedayati et al. (2016) \\
\hline \multirow[t]{3}{*}{ Luciobarbus pectoralis } & Menzelet Reservoir, Turkey & Male & 77 & $\mathrm{TL}$ & $16.5-20.6$ & 0.0639 & 2.418 & 0.404 & Ozcan \& Ispir (2019) \\
\hline & & Female & 73 & $\mathrm{TL}$ & $15.5-21.0$ & 1.0630 & 1.228 & 0.565 & \\
\hline & & Both & 150 & $\mathrm{TL}$ & $15.5-21.0$ & 0.0670 & 1.778 & 0.439 & \\
\hline Luciobarbus pectoralis & Seyhan Reservoir, Turkey & Mixed & 102 & $\mathrm{TL}$ & $15.5-33.5$ & 0.00530 & 3.225 & 0.975 & Erguden (2016) \\
\hline
\end{tabular}

The present data should be considered as representing only a particular season or time of year. Besides, the parameters of $b$ generally do not vary significantly throughout the year, unlike parameter a, which may vary seasonally, daily, and between habitats (Bagenal \& Tesch, 1978; Goncalves et al., 1997). According to Tesch (1971), the length-weight relationship in fishes is affected by some factors including season, gonad maturity, diet, habitat, sampling, and also preservation techniques. In the present study, these factors were not taken into account.

L. pectoralis has commercial economic value and also local fishermen catch and consume it as food in this region. In recent years, L. pectoralis population has been decreasing in the Asi River Basin. The main important reasons for the decline in the abundance of this fish species may be due to overfishing, destruction of their spawning grounds, restrictions in their habitats, and pollution.
Today $L$. pectoralis is considered as Least Concern (LC) in the IUCN Global Red List for Anatolian waters (IUCN, 2020). However, this species has affected and decreased from large parts of the Asi drainage due to pollution, habitat destruction, and water abstraction. Unfortunately, many threats are still not considered due to not enough substantial evidence for this species. Thus, further research is required to reveal details about the habitats situations of regional species in this region.

In the present study, we report the first references available for the length-weight (LWRs) and length-length relationships (LLRs) of the Levantine barbelfrom Asi River (Southeastern Anatolia, Turkey). Besides, the present study the maximum total length was determined as $38 \mathrm{~cm}$, and this is the new maximum length reported from Turkish inland waters. The results of this study will be useful for fisheries biologists and conservation experts for 
the sustainable use of the L. pectoralis population in the Asi River.

\section{ACKNOWLEDGEMENTS}

I would like to thank Murat Devecili for his assistance.

\section{REFERENCES}

Almaça, C. (1986). On some Barbus species from western Asia (Cyprinidae, Pisces). Annalen des Naturhistorischen Museums in Wien, 87, 5-30.

Alp, A., Kara, C.H., Büyükçapar, M. \& Bülbül, O. (2005). Age, growth and condition of Capoeta capoeta angorae, Hanko 1924 from the upper water systems of the River Ceyhan, Turkey. Turkish Journal of Veterinary and Animal Sciences, 29, 665-676.

Bagenal, T.B. \& Tesch, F.W. (1978). Age and growth, In: Bagenal, T.B. (Ed), Methods for assessment of fish production in freshwaters, 3rd edition,101136p, Blackwell Scientific Publications, Oxford, UK.

Basiacik, S., Sari, H.M., Ilhan, A. \& Ustaoglu, M.R. (2012). Some growth features of barbel fish population (Luciobarbus kottelati Turan, Ekmekçi, İlhan \& Engin, 2008) in Adıgüzel Dam Lake (Denizli). Journal of FisheriesSciences.com, 6(1), 32-38. DOI: 10.3153/jfscom.2012005

Coban, M.Z., Turkgulu, I., Yuksel, F., Celayir, Y., Yuce, S., Eroğlu M. \& Şen, D. (2012). Some biological characteristics of Luciobarbus esocinus Heckel, 1843 living in Keban Reservoir. Turkish Journal of Fisheries and Aquatic Sciences, 12, 7380. DOI: 10.4194/1303-2712-v12_1_09

Dartay, M. \& Gul, M.R. (2013). Length-weight relationships for five fish species Caught in Keban Dam Lake, Turkey. Journal of Applied Ichthyology, 30(1), 233-234. DOI: 10.1111/jai.12208

Erguden, S.A. (2016). Length-weight relationships for six freshwater fish species from the Seyhan Reservoir (south-eastern Anatolia, Turkey). Journal of Applied Ichthyology, 32, 141-143. DOI: 10.1111/jai.12905

Fricke, R., Bilecenoglu, M. \& Sari, H.M. (2007). Annotated checklist of fish and Lamprey species (Gnathostoma and Petromyzontomorphi) of Turkey, including a Red List of threatened and declining species. Stuttgarter Beiträgezur Naturkende, Seria A (Biologie), 706, 1-172.

Froese, R. (2006). Cube law, condition factor and weightlength relationships: History, meta-analysis and recommendations. Journal of Applied Ichthyology, 22, 241-253. DOI: 10.1111/j.14390426.2006.00805.x

Froese, R. \& Pauly, D. (2020). Fishbase. Worldwide web electronic https://www.fishbase.se/summary/54714. (11.07.2020).

Freyhof, J. (2014). Luciobarbus pectoralis. The IUCN Red List of Threatened Species 2014: e. T19383495A19848388. DOI: 10.2305/IUCN.UK.20141.RLTS.T19383495A19 848388.en. (10.07.2020).

Geldiay, R. \& Balık, S. (1999). Türkiye tatlısu balıkları, EgeÜniversitesi Su Ürünleri Fakültesi Yayınları, No: 46, Ders Kitabı Dizini, No: 16, Izmir, Turkey, $532 \mathrm{p}$.

Goncalves, J.M.S., Bentes, L., Lino, P.G., Ribeiro, J., Canario, A.V.M. \& Erzini, K. (1997). Weightlength relationships for selected fish species of the small-scale demersal fisheries of the south and south-west coast of Portugal. Fisheries Research, 30, 253-256. DOI: 10.1016/S01657836(96)00569-3

Hedayati, S.A., Farsani, H.G. \& Gerami, M.H. (2016). Length-weight relationships of two fish species from Gamasiab Reservoir, western Iran: Alburnus mossulensis Heckel, 1843 and Luciobarbus esocinus Heckel, 1843. Journal of Applied Ichthyology, 32, 139-140. DOI: 10.1111/jai.12915

IUCN. (2020). The IUCN Red List of threatened species. Version 2020-1. https://www.iucnredlist.org /species/19383495/19848388. (11.07.2020).

Karaman, L.S. (1971). Süsswasserfische der Türkei, 8. Teil, revision der Barben Europas, vorder asiens und nord Afrikas. Mitteilungenausdem Hamburgischen Zoologischen Museum und Institute, 67, 175-254.

Kottelat, M. \& Freyhof, J. (2007). Handbook of European freshwater fishes, Kottelat, Cornol, Switzerland and Freyhof, XIV, Berlin, Germany, $646 \mathrm{p}$.

Kuru, M. (2004). Recent systematic status of inland fishes of Turkey. Gazi Üniversitesi, Gazi Ĕ̆itim Fakültesi Dergisi, 2(3), 1-21.

Le Cren, E.D. (1951). The length-weight relationship and seasonal cycle in gonad weight and condition in perch, Perca fluviatilis. Journal of Animal Ecology, 20, 201-219.

Moutopoulos, D.K. \& Stergiou, K.I. (2002). Lengthweight and length-length relationships of fish species from the Aegean Sea (Greece). Journal of Applied Ichthyology, 18, 202-203. DOI: 10.1046/j.1439-0426.2002.00281.x

Ozcan, G. (2013). A contribution to knowledge of the freshwater fish of Orontes River, Hatay, Turkey. Proceedings of the International Academy of Ecology and Environmental Sciences, 3(2), 143147.

Ozcan, M. \& Ispir, U. (2019). Lenght-weight relationships of Luciobarbus pectoralis from the Menzelet Dam Lake of Kahramanmaraş. Agricultural Journal, 14(3), 35-39.

Pauly, D. (1984). Fish population dynamics in tropical waters: A manual for use with programmable calculators. ICLARM Studies and Reviews 8, 
International Center for Living Aquatic Resource Management, Manila, Philippines, 325p.

Ricker, W.E. (1975). Computation and interpretation of biological statistics of fish populations. Bulletin Fisheries Research Board of Canada, 191, 1-382.

Santos, M.N., Gaspar, M.B., Vasconcelos, P. \& Monteiro, C.C. (2002). Weight-length relationships for 50 selected fish species of the Algarve coast (southern Portugal). Fisheries Research, 59, 289-295. DOI: 10.1016/S01657836(01)00401-5

Tarkan, A.S., Gaygusuz, O., Acipinar, H., Gürsoy, C. \& Ozulug, M. (2006). Length-weight relationship of fishes from the Marmara region (NW-Turkey). Journal of Applied Ichthyology, 22, 271-273. DOI: 10.1111/j.1439-0426.2006.00711.x

Tesch, F.W. (1971). Age and growth, In: Ricker W.E. (Ed), Methods for assessment of fish production in fresh waters, 98-130p. Oxford, Blackwell Scientific Publications, UK.

Turan, D., Ekmekçi, F.G., İlhan, A. \& Engin, S. (2008). Luciobarbus kottelati, A new species of barbel (Teleostei: Cyprinidae) from the Büyük Menderes River, Turkey, with rediagnose of L. lydianus. Zootaxa, 1824, 35-44. DOI: 10.11646/zootaxa.1824.1.4

Wootton, R.J. (1998). Ecology of teleost fishes, 2nd Edition, Kluwer Academic Publishers, Dordrecht, Boston, 386p. 